\title{
Sleep alterations in patients with the human immunodeficiency virus and chronic pain
}

\author{
Alterações do sono em pacientes vivendo com o vírus da imunodeficiência humana e dor crônica
}

Glória Pinto Soares de Aguiar ${ }^{1}$, Jairo Alberto Dussán-Sarria², Andressa de Souza ${ }^{3}$

DOI 10.5935/2595-0118.20190023

\section{ABSTRACT}

BACKGROUND AND OBJECTIVES: In patients with chronic pain, insomnia is reported between 50 and $88 \%$ of them. It is essential to recognize sleep disorders to estimate its repercussions on the quality of life and to seek knowledge that supports the necessary interventions. This study aims to identify the possible factors that influence sleep quality, as well as its prevalence in these patients.

METHODS: Sample consisting of 68 patients (58 women, 10 men), the mean age of $45.3 \pm 10.3$ years, with a positive diagnosis of human immunodeficiency virus undergoing antiretroviral and chronic pain treatment in Porto Alegre, RS. The Pittsburgh Sleep Quality Index was used to assess the components of the scale as well as their overall score. For the classification of the type of chronic pain, the Leeds Assessment of Neuropathic Symptoms and Signs scale was used, which differentiates nociceptive and neuropathic pain.

RESULTS: Patients classified with no pain, nociceptive pain and neuropathic pain. Overall score divided into good sleep, bad sleep and sleep disorder, where patients without pain accounted for $8.8 \%$, 16.2 and $2.9 \%$ respectively. With nociceptive pain 4.4, 11.8 and $5.9 \%$, respectively. With neuropathic pain 4.4, 23.5 and $22.1 \%$ respectively. Patients with neuropathic pain had the highest rates of poor sleep and sleep disorder, accounting for $50.0 \%$ and using more sleeping pills compared to the control group $(\mathrm{p}<0.05)$.

CONCLUSION: There is a high prevalence of sleep disorders or poor sleep in patients with the human immunodeficiency virus with neuropathic pain. The importance of assessing the sleep as

Glória Pinto Soares de Aguiar - Dhttps://orcid.org/0000-0002-5468-4730;

Jairo Alberto Dussán-Sarria - Dhttps://orcid.org/0000-0002-1271-0638;

Andressa de Souza - Dhttps://orcid.org/0000-0002-6608-4695.

1. Universidade La Salle, Programa de Pós-Graduação em Saúde e Desenvolvimento Humano, Canoas, RS, Brasil.

2. Hospital de Clínicas de Porto Alegre, Serviço de Anestesiologia e Medicina Perioperatória, Porto Alegre, RS, Brasil.

3. Universidade Federal do Rio Grande do Sul. Programa de Pós-Graduação em Ciências Biológicas: Farmacologia e Terapêutica, Porto Alegre, RS, Brasil.

Submitted on August 01, 2018.

Accepted for publication on March 18, 2019.

Conflict of interests: none - Sponsoring sources: Conselho Nacional de Desenvolvimento Científico e Tecnológico - CNPq. Edital CNPQ-Universal (442479/2014-0).

Correspondence to:

Av. Victor Barreto, 2288, Prédio 7

92010-000 Canoas, RS, Brasil.

E-mail: andressasz@gmail.com

(C) Sociedade Brasileira para o Estudo da Dor an essential part of the clinical assessment should be recognized and incorporated without delay by health professionals.

Keywords: Chronic pain, Human immunodeficiency virus, Nursing, Sleep.

\section{RESUMO}

JUSTIFICATIVA E OBJETIVOS: Em pacientes com dor crônica, a insônia é relatada entre 50 e $88 \%$ deles. É fundamental reconhecer as alteraçóes do sono para estimar suas repercussóes na qualidade de vida e buscar conhecimentos que respaldem as necessárias intervençóes. Este estudo buscou identificar os possíveis fatores que influenciam a qualidade do sono, bem como suas prevalências nesses pacientes.

MÉTODOS: Amostra constituída por 68 pacientes $(58$ mulheres e 10 homens) com idade média de 45,3 $\pm 10,3$ anos, diagnóstico positivo para o vírus da imunodeficiência humana em tratamento antirretroviral e dor crônica, de uma instituição em Porto Alegre, RS. O Questionário do Índice de Qualidade de Sono de Pittsburgh foi usado para a avaliação dos componentes da escala de sono, bem como sua pontuação total. Para a classificação do tipo de dor crônica foi utilizada a escala Leeds Assessment of Neuropathic Symptoms and Signs, que diferencia dor nociceptiva e neuropática. RESULTADOS: Os pacientes foram classificados em sem dor, dor nociceptiva e dor neuropática. A pontuação global foi dividida em sono bom, sono ruim e distúrbio do sono, onde os pacientes sem dor representaram 8,8, 16,2 e 2,9\% respectivamente. Com dor nociceptiva 4,4, 11,8 e 5,9\% respectivamente. Com dor neuropática 4,4, 23,5 e 22,1\% respectivamente. Os pacientes com dor neuropática apresentaram os maiores índices de sono ruim e distúrbio do sono, representando 50,0\% e utilizavam mais fármacos para dormir em comparação com o grupo controle $(p<0,05)$.

CONCLUSÃO: Existe elevada prevalência de distúrbios do sono ou sono ruim em pacientes portadores do vírus com dor neuropática. A importância da avaliação do sono como parte essencial da avaliação clínica deve ser reconhecida e incorporada sem demora pelos profissionais de saúde.

Descritores: Dor crônica, Enfermagem, Sono, Vírus da imunodeficiência humana.

\section{INTRODUCTION}

The human immunodeficiency virus (HIV) attacks the immune system destroying the defense cells, $\mathrm{CD}^{+} \mathrm{T}$ lymphocytes, causing an immunosuppression picture. Immunode- 
ficiency is characterized by continuous viral replication and depletion of $\mathrm{CD}^{+}$T-lymphocytes, affecting the capacity of the immune system to defend the body from foreign or anomalous cells that invade or attack it, such as bacteria, viruses, fungi, and cancer cells ${ }^{1}$.

As the lymphatic system and immune responses slowly collapse, an HIV-infected person becomes more susceptible to opportunistic infections, getting sicker more often. This condition of susceptibility due to the lymphatic system and defective immune responses is diagnosed as Acquired Immunodeficiency Syndrome (AIDS), characterized not by a symptom, but by a set of signs and symptoms arising from a decrease in the $\mathrm{CD}^{+} \mathrm{T}$-cell lymphocyte count.

AIDS is diagnosed when the T-cell count falls below 200 per microliter of blood. The $\mathrm{CD}^{+}{ }^{+} \mathrm{T}-$-lymphocyte count, and the viral load are important prognostic markers to monitor the infection and to follow-up the disease progression in these patients ${ }^{1}$. According to the Joint United Nations Program on HIV/ $\mathrm{AIDS}^{3}$, the number of people living with HIV/AIDS in the world is approximately 36.7 million. The report shows that antiretroviral therapy is providing a longer life to people with HIV. In 2015, people over the age of 50 accounted for about $17 \%$ of the adult population (15 years or older) living with HIV. In high-income countries, $31 \%$ of people living with HIV were over 50 years old ${ }^{3}$.

In Brazil, from 1980 to 2016, 548,850 (65.1\%) cases of AIDS in men and 293,685 (34.9\%) in women were registered. Over the last 10 years, AIDS detection rates in men have shown a growth trend. In 2006 the rate was 24.1 cases per 100 thousand inhabitants, reaching 27.9 in 2015, an increase of $15.9 \%$.

According to the HIV/AIDS Epidemiological Bulletin of the Department of Surveillance of the Ministry of Health, published annually, in 2015 there were 39,113 new cases of HIV infection in Brazil. The city of Porto Alegre presented a rate of 74 cases for 100 thousand inhabitants, corresponding to twice the rate of the State of Rio Grande do Sul and almost four times the rate of Brazil. The AIDS detection rate in Brazil has stabilized in the last 10 years, with an mean of 20.7 cases per 100,000 inhabitants. The recommendation for the treatment of people with HIV, regardless of CD4 count, is in place since December 2013. In June 2016, around 18.2 million people worldwide had access to the antiretroviral treatment, including 910,000 children, twice the number registered five years earlier.

As people with HIV become older, they are also more susceptible to the long-term adverse effects of the antiretroviral treatment, developing resistance to drugs, and requiring the treatment of comorbidities, such as tuberculosis and hepatitis $\mathrm{C}$, among others, that may also interact with the antiretroviral therapy. Ongoing research and investments are needed to discover simpler and more tolerable treatments for HIV and comorbidities, as well as to discover a vaccine and the cure for the virus ${ }^{3}$.

The use of combined antiretroviral therapy, available at the Brazilian public services since 1997, has determined a new course for the disease ${ }^{5}$. Controlling the virus replication and the consequent improvement of patients' immunity, AIDS has taken the characteristics of chronic disease, increasing the life expectancy of patients ${ }^{6}$. Unfortunately, even providing patients with a longer life expectancy, the mechanism of action of the drugs brings chronic complications not directly related to the HIV infection, such as cardiovascular diseases, liver, renal and bone alterations, as well as neoplasms and loss of neurocognitive functions and neuropathologies ${ }^{1}$.

Neurological manifestations are frequent in people with HIV, being the first manifestation of the disease in $10 \%$ of cases, and between 30 and $50 \%$ of patients will report neurological symptoms at some point in life. Peripheral neuropathies are commonly associated with HIV infections, and distal peripheral neuropathy is the most frequent symptomatic form in $35 \%$ of the patients ${ }^{7,8}$.

The neuropathic pain in HIV patients is a result of changes in the immune system, due to immunosuppression?. Immunosuppression makes the individual more susceptible to infections and malignancies, which are aggravated by the huge negative interaction of drugs used for analgesia and the antiretrovirals, making it difficult to treat painful symptoms in these patients, reducing their quality of life $(\mathrm{QoL})^{10}$.

Statistics show that $30 \%$ of the world's population suffers from chronic pain ${ }^{11}$. In Brazil, this number reaches almost 60 million people, with $50 \%$ reporting serious impair to their routine. Larue, Fontaine and Colleau ${ }^{12}$ found that in the HIV/AIDS population, $30 \%$ of outpatients and $62 \%$ of hospitalized patients due to HIV reported HIV-related pain and that their severity was significantly underestimated by the physicians who cared seropositive patients. In adults with HIV, neuropathic pain is more common in men with low CD4 levels or increased viral load. In this population, $80 \%$ of patients report experiencing intense pain, which interferes with the mood, QoL and work capacity.

It is known that QoL is directly related to sleep quality, among other factors. ${ }^{13}$. Sleep, characterized by the temporary suspension of the sensory and perceptive voluntary motor activity, is part of the basic needs of the human being, as well as eating and drinking, having a restorative function for the organism and the brain ${ }^{14}$. Studies have related sleep to the immune function, indicating that its deprivation may compromise this function ${ }^{15}$. Experimentally sleep-deprived subjects have decreased the NK (Natural Killer) cells activity, which is part of the innate immunity, accounting for about 10 to $20 \%$ of the circulating lymphocytes ${ }^{16}$.

According to the World Health Organization ${ }^{17}$, about $40 \%$ of the world population does not sleep as desired and has some of the more than 80 sleep disorders and syndromes listed by the International Classification of Sleep Disorders (ICSD). In addition, it is known that sleep disorders are a significant impact factor in a person's life, causing short- or long-term impairment in daily activities, social, somatic, psychological or cognitive adversities ${ }^{18}$ and according to the Brazilian Sleep Association, sleep disorders can have important repercussions on performance and social costs. Estimates of the rate of accidents and deaths caused by drowsiness or fatigue vary from 
2 to $41 \%$, with a high cost in financial and life terms involving economic and health issues, such as increased hospitalizations, absenteeism, traffic accidents and the development of mental disorders ${ }^{19}$.

Patients with AIDS have many complaints, especially regarding chronic pain and adverse reactions of the antiretroviral treatment, and it is also expected to find complains related to sleep quality ${ }^{20}$.

The diagnosis of sleep disorders is not so easy because most people are unaware that this is a clinical condition that can be treated. Because of this lack of knowledge, patients fail to report sleep problems, and due to the lack of knowledge of most health professionals in identifying such disorders, there is no input to a diagnosis and treatment, thus increasing the worsening of symptoms ${ }^{19}$.

Since sleep is a basic human need, its preservation and maintenance are fundamental for the individual to have a healthy life. It is important to recognize and relate these difficulties in order to seek knowledge that supports the necessary nurse interventions to improve the $\mathrm{QoL}^{21}$.

Nurses, as health professionals, play a fundamental role in the promotion, prevention, and care of health problems. It is believed that such an understanding is essential for the planning of decisive actions in this context ${ }^{22}$.

The objective of this study was to identify the possible factors that impact sleep quality as well as the prevalence in patients with HIV.

\section{METHODS}

A cross-sectional cohort study, with a quantitative approach, conducted at a Non-Governmental Organization (NGO) in Porto Alegre/RS, where participants were included in the study according to the following inclusion criteria: confirmed diagnosis of HIV/AIDS in treatment with antiretroviral therapy; aged between 18 and 65 years, of both genders; and Free and Informed Consent Term (FICT) understood and signed. The exclusion criteria were active acute contagious infection (meningitis, active pulmonary tuberculosis); history of chronic diseases associated with neuropathy (diabetes, lupus, rheumatoid arthritis); HTLV infection (Human T-cell Lymphotrophic Virus); chronic renal failure; peripheral vascular disease; use of systemic corticosteroids; cancer; severe disease that would limit the understanding of the FICT or the questionnaires.

Data collection was from August to December 2015. The data were collected when the subjects had an appointment at the NGO. The interviews were in a private room, before or after the care visit.

Semi-structured data collection forms were used for data collection, which included questions related to the patient's identification, socioeconomic profile, health history, and treatment.

The Pittsburgh Sleep Quality Index (PSQI-BR) questionnaire was used, an American questionnaire validated for the Portuguese language, which characteristic is the evaluation of sleep quality in the last month ${ }^{23}$. This questionnaire has 19 ques- tions that configure seven components of sleep evaluation: quality, latency, duration, efficiency, nocturnal disorders, use of sleeping pills and daytime sleepiness. Each component receives a score ranging from zero to three so that the instrument's final score can range from zero to 21 . The higher the score, the worse the sleep quality, and values higher than five indicate poor quality sleep.

For the classification of the chronic pain, the Leeds Assessment of Neuropathic Symptoms and Signs (LANSS) was used. This scale is validated in Brazil and used to differentiate nociceptive pain from neuropathic pain ${ }^{24}$.

All the 68 patients who made up this sample has completed $100 \%$ of the data related to the PSQI-BR questionnaire and were evaluated in accordance with the mentioned tests.

Considering that the description of the quality of sleep in patients with HIV/AIDS, evaluated for the Pittsburgh scale would be one of the most significant contributions of the present study to the scientific literature, the size of the sample was calculated on this outcome. Ferreira and Ceolim ${ }^{26}$ described that patients with HIV have a high prevalence of poor sleep quality. The effect size was 1.35 (Cohen's D). Sample size calculation was performed with a two-tailed alpha error of $0.05,95 \%$ power and equal sample size. The calculation of the sample size was performed by the Gpower software.

According to the ethical recommendations of the Ministry of Health, the development of the study is in accordance with Resolution 466/12 - National Health Council (CNS), which deals with human research ethics ${ }^{25}$. The patients were informed about the purpose of the study and agreed to participate signed the FICT. They were also told that they could withdraw at any time, without any discontinuation of their care. At the end of the study, the institution where the study was conducted had all data available, as well as all those who might be interested. This study is part of a larger project entitled "Neurophysiology of Nociception and Central Sensitization in Patients with HIV Neuropathy", coordinated by Prof. Dr. Andressa de Souza and collaborators, of the Graduate Program in Health and Human Development, line of Pathological Processes Research, funded by the National Council for Scientific and Technological Development - CNPq (Universal 442479 / 2014-0), with Certificate of Presentation for Ethical Appraisal (CAAE) number 30388114.3.0000.5307 and with the opinion of approval number 647.372. University La Salle.

\section{Statistical analysis}

The data were summarized using conventional descriptive statistics. Continuous variables were described using mean, median and standard deviation. Categorical variables were described using absolute numbers and percentages. The comparison between the groups for the continuous variables was performed using the Kruskal-Wallis test. The comparisons between the categorical variables were performed using the Chisquare test or Fisher's Exact test, accordingly. For all analysis, the level of statistical significance for the established alpha error was a two-tailed $\mathrm{p}<0.05$. Analyzes were processed using SPSS version 20.0 (SPSS, Chicago, IL). 


\section{RESULTS}

The sample consisted of 68 patients with a mean age of $45.3 \pm 10.3$ years, all with a confirmed diagnosis of HIV/AIDS in treatment with antiretroviral therapy. Of the 68 patients, 15 live alone, 49 (72.0\%) live with the family, that could be spouse, parents or children, and 04 (6.0\%) do not fit the previous ones. As for the time of schooling, the mean is 5.9 years.

Table 1. Characterization of the sample regarding sociodemographic data and lifestyle

\begin{tabular}{llcc}
\hline Variables & & Frequency & $\%$ \\
\hline Gender & Male & 10 & 14.7 \\
Age (years) & Female & 58 & 85.3 \\
& Between 35 and 55 & 46 & 67.7 \\
& More than 55 & 13 & 19.1 \\
Housing & Less than 35 & 9 & 13.2 \\
& Living alone & 15 & 22.0 \\
Schooling & Living with family & 49 & 72.0 \\
& Other types of housing & 4 & 6.0 \\
Professional work & Mean years of study & 5.9 & \\
& Median years of study & 5 & \\
& Active & 14 & 21.0 \\
& Unemployed & 27 & 40.0 \\
Viral load & Social allowance & 25 & 37.0 \\
& Undetectable & 31 & 45.6 \\
& Not informed & 3 & 4.4 \\
& Detectable & 34 & 50.0 \\
Use of Efavirenz & Using & 17 & 25.0 \\
& Not using & 51 & 75.0 \\
\hline
\end{tabular}

Regarding the professional occupation, 27 (40.0\%) are unemployed. The viral load is detectable in 34 (50.0\%) patients. In this sample, all patients are being treated with antiretroviral therapy, and only 17 (25.0\%) patients used the non-nucleoside reverse transcriptase inhibitor Efavirenz. Table 1 shows the data obtained.

Regarding the perceived pain, only $31 \%$ reported no pain and the remaining $69 \%$ reported pain in the head (46\%), upper limbs (41\%), chest (43\%) and lower limbs (43\%).

In this study, the patients were classified according to the LANSS scale ${ }^{24}$, which differentiates nociceptive from neuropathic pain. Thus, patients were subdivided into a control group (no pain, $n=19)$, nociceptive pain $(n=15)$, and neuropathic pain $(n=34)$. The results are shown in Table 2 .

Regarding the usual sleep characteristics, the patients were also divided between control (no pain), nociceptive pain and neuropathic pain groups. The results are shown in table 3 . Of the total sample, 35 (51.5\%) had habitual sleep efficiency above 85\%, 13 (19.1\%) between 75 and $84 \%, 10$ (14.7\%) between 65 and $74 \%$ and $10(14.7 \%)$ had sleep efficiency lower than 65\%.

In the sleep quality analysis, obtained with the PSQI-BR, the indexes of subjective quality, latency, duration, efficiency, disturbances, use of sleeping pills and daytime sleepiness are correlated. The values of these indices are shown in table 4 .

According to the PSQI-BR, the following factors that cause considerable difficulties to sleep were evaluated in the sample: cough or loud snoring, taking more than 30 minutes to get to sleep, getting up to go to the bathroom, waking up in the middle of the night or too early, have difficulty breathing, feel very cold, feel very hot, have bad dreams or nightmares, feel pain and other reasons, as shown in table 5 . Of these factors, the following stand out especially in the neuropathic pain group; get up to go to the bathroom, $20(29.4 \%)$ patients; take more

Table 2. Sociodemographic and clinical characteristics with a significant association with the classification of the with pain and without pain groups in patients with HIV/AIDS

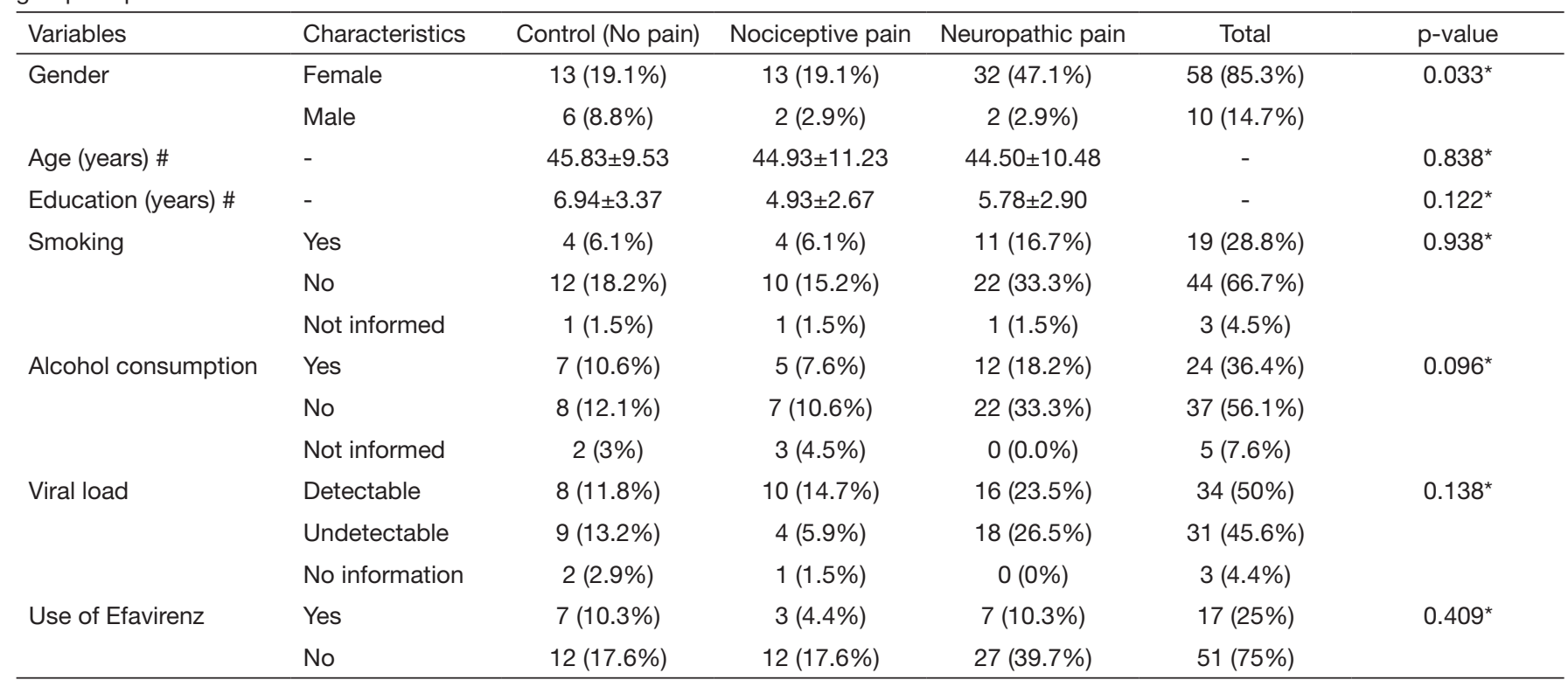

Variables expressed in absolute numbers (percentage). \# variable shown as mean \pm SD of the mean. ${ }^{*}$ Exact Fisher and Kruskal-Wallis tests. $\mathrm{p}<0.05$ was considered a significant difference. 
Table 3. Regarding the usual sleep characteristics, the patients were also divided into control (no pain), nociceptive pain and neuropathic pain groups

\begin{tabular}{|c|c|c|c|c|c|c|c|c|c|c|}
\hline \multirow[t]{2}{*}{ Usual sleep characteristics } & \multicolumn{3}{|c|}{ Control (no pain) } & \multicolumn{3}{|c|}{ Nociceptive pain } & \multicolumn{3}{|c|}{ Neuropathic pain } & \multirow[t]{2}{*}{$p$-value } \\
\hline & Mean & SD & Median & Mean & SD & Median & Mean & SD & Median & \\
\hline Time to go to bed & 23.000 & 1.452 & 23.000 & 22.666 & 2.160 & 22.000 & 23.029 & 1.678 & 23.000 & $0.701^{*}$ \\
\hline Latency (minutes) & 43.421 & 65.448 & 15.000 & 57.400 & 61.719 & 30.000 & 51.323 & 48.073 & 30.000 & $0.218^{*}$ \\
\hline Wake-up time & 7.105 & 1.696 & 7.000 & 6.933 & 1.944 & 7.000 & 7.088 & 1.896 & 7.000 & $0.820^{*}$ \\
\hline Sleep duration (hours) & 7.111 & 1.449 & 7.000 & 7.400 & 1.993 & 8.000 & 6.650 & 2.281 & 6.000 & $0.225^{\star}$ \\
\hline \multicolumn{11}{|l|}{ Usual sleep efficiency } \\
\hline$>85 \%$ & \multicolumn{3}{|c|}{$12(17.6 \%)$} & \multicolumn{3}{|c|}{$8(11.8 \%)$} & \multicolumn{3}{|c|}{$15(22.1 \%)$} & $0.336 \#$ \\
\hline 75 to $84 \%$ & \multicolumn{3}{|c|}{$3(4.4 \%)$} & \multicolumn{3}{|c|}{$3(4.4 \%)$} & \multicolumn{3}{|c|}{$7(10.3 \%)$} & \\
\hline 65 to $74 \%$ & \multicolumn{3}{|c|}{2 (2.9\%) } & \multicolumn{3}{|c|}{$0(0.0 \%)$} & \multicolumn{3}{|c|}{$8(11.8 \%)$} & \\
\hline$<65 \%$ & \multicolumn{3}{|c|}{2 (2.9\%) } & \multicolumn{3}{|c|}{4 (5.9\%) } & \multicolumn{3}{|c|}{4 (5.9\%) } & \\
\hline Total & \multicolumn{3}{|c|}{19 (27.9\%) } & \multicolumn{3}{|c|}{15 (22.1\%) } & \multicolumn{3}{|c|}{34 (50.0\%) } & \\
\hline
\end{tabular}

For sleep efficiency, the variables are expressed in absolute numbers (percentage). SD of the mean; ${ }^{*}$ Kruskal Wallis test. \# Fisher's Exact test; $p<0.05$ was considered a significant difference.

Table 4. Comparison of overall PSQI-BR score and components among patients without pain, nociceptive pain or neuropathic pain

\begin{tabular}{|c|c|c|c|c|c|c|c|c|c|c|}
\hline \multirow[t]{2}{*}{ PSQI-BR components } & \multicolumn{3}{|c|}{ Control (no pain) } & \multicolumn{3}{|c|}{ Nociceptive pain } & \multicolumn{3}{|c|}{ Neuropathic pain } & \multirow[t]{2}{*}{$\mathrm{p}$-value } \\
\hline & Mean & SD & Median & Mean & SD & Median & Mean & SD & Median & \\
\hline Subjective sleep quality & 1.500 & 0.730 & 1.000 & 1.500 & 0.650 & 1.000 & 1.727 & 0.801 & 2.000 & $0.529^{*}$ \\
\hline Sleep latency & 1.263 & 1.284 & 1.000 & 1.666 & 1.234 & 2.000 & 1.970 & 1.086 & 2.000 & $0.148^{*}$ \\
\hline Sleep duration & 0.736 & 0.933 & 0.000 & 0.866 & 1.125 & 0.000 & 1.294 & 1.268 & 1.000 & $0.276^{*}$ \\
\hline Sleep efficiency & 0.684 & 1.056 & 0.000 & 1.000 & 1.309 & 0.000 & 1.029 & 1.086 & 1.000 & $0.477^{*}$ \\
\hline Sleep disorders & 1.578 & 0.507 & 2.000 & 2.000 & 0.755 & 2.000 & 1.911 & 0.621 & 2.000 & $0.119^{*}$ \\
\hline Sleeping pills & 0.157 & 0.688 & 0.000 & 1.000 & 1.463 & 0.000 & 1.058 & 1.412 & 0.000 & $0.038^{*}$ \\
\hline Daytime sleepiness & 0.894 & 0.936 & 1.000 & 0.866 & 0.743 & 1.000 & 1.323 & 1.000 & 1.006 & $0.192^{*}$ \\
\hline \multicolumn{11}{|l|}{ Overall score (\%) } \\
\hline Good sleep & \multicolumn{3}{|c|}{$6(8.8 \%)$} & \multicolumn{3}{|c|}{$3(4.4 \%)$} & \multicolumn{3}{|c|}{$3(4.4 \%)$} & 0.059\# \\
\hline Poor sleep & \multicolumn{3}{|c|}{$11(16.2 \%)$} & \multicolumn{3}{|c|}{$8(11.8 \%)$} & \multicolumn{3}{|c|}{$16(23.5 \%)$} & \\
\hline Sleep disorder & \multicolumn{3}{|c|}{$2(2.9 \%)$} & \multicolumn{3}{|c|}{$4(5.9 \%)$} & \multicolumn{3}{|c|}{$15(22.1 \%)$} & \\
\hline Total & \multicolumn{3}{|c|}{19 (27.9\%) } & \multicolumn{3}{|c|}{15 (22.1\%) } & \multicolumn{3}{|c|}{34 (50.0\%) } & 0.059 \\
\hline
\end{tabular}

Overall sleep score, data expressed in absolute numbers (percentage). \# Fisher's Exact test; ${ }^{\star}$ Kruskal-Wallis test; $p<0.05$ was considered a significant difference.

Table 5. Factors that have caused, more frequently, difficulty to fall asleep among patients without pain, nociceptive pain or neuropathic pain

\begin{tabular}{|c|c|c|c|c|c|}
\hline Variables & Occurrence & Control (no pain) & Nociceptive pain & Neuropathic pain & $p$-value \\
\hline \multirow[t]{4}{*}{ Cough or snore very loud } & Never & $13(19.1 \%)$ & $9(13.2 \%)$ & $15(22.1 \%)$ & $0.592^{*}$ \\
\hline & Less than once a week & $1(1.5 \%)$ & $1(1.5 \%)$ & $1(1.5 \%)$ & \\
\hline & Once-twice a week & $2(2.9 \%)$ & $2(2.9 \%)$ & $6(8.8 \%)$ & \\
\hline & 3 times/week or more & $3(4.4 \%)$ & $4(4.4 \%)$ & $12(17.6 \%)$ & \\
\hline \multirow{4}{*}{$\begin{array}{l}\text { Take more than } 30 \text { minutes to fall } \\
\text { asleep }\end{array}$} & Never & $7(10.3 \%)$ & $4(5.9 \%)$ & $8(11.8 \%)$ & $0.647^{*}$ \\
\hline & Less than once a week & $2(2.9 \%)$ & $2(2.9 \%)$ & $1(1.5 \%)$ & \\
\hline & Once-twice a week & $3(4.4 \%)$ & $3(4.4 \%)$ & $6(8.8 \%)$ & \\
\hline & 3 times/week or more & 7 (10.3\%) & $6(8.8 \%)$ & $19(27.9 \%)$ & \\
\hline \multirow[t]{4}{*}{ Get up to go to the bathroom } & Never & $2(2.9 \%)$ & $3(4.4 \%)$ & $4(5.9 \%)$ & $0.694^{*}$ \\
\hline & Less than once a week & $1(1.5 \%)$ & $0(0.0 \%)$ & $1(1.5 \%)$ & \\
\hline & Once-twice a week & $4(5.9 \%)$ & $1(1.5 \%)$ & $9(13.2 \%)$ & \\
\hline & 3 times/week or more & $12(17.6 \%)$ & $11(16.2 \%)$ & $20(29.4 \%)$ & \\
\hline
\end{tabular}


Table 5. Factors that have caused, more frequently, difficulty to fall asleep among patients without pain, nociceptive pain or neuropathic pain continuation

\begin{tabular}{|c|c|c|c|c|c|}
\hline Variables & Occurrence & Control (no pain) & Nociceptive pain & Neuropathic pain & $p$-value \\
\hline \multirow{4}{*}{$\begin{array}{l}\text { Waking up in the middle of the } \\
\text { night or early morning }\end{array}$} & Never & $5(7.4 \%)$ & $1(1.5 \%)$ & $2(2.9 \%)$ & $0.114^{*}$ \\
\hline & Less than once a week & $1(1.5 \%)$ & $0(0.0 \%)$ & $6(8.8 \%)$ & \\
\hline & Once-twice a week & $5(7.4 \%)$ & $2(2.9 \%)$ & $7(10.3 \%)$ & \\
\hline & 3 times/week or more & $8(11.8 \%)$ & $12(17.6 \%)$ & 19 (27.9\%) & \\
\hline \multirow[t]{4}{*}{ Difficult breathing } & Never & $14(20.6 \%)$ & $9(13.2 \%)$ & $23(33.9 \%)$ & $0.928^{*}$ \\
\hline & Less than once a week & $1(1.5 \%)$ & $2(2.9 \%)$ & $1(1.5 \%)$ & \\
\hline & Once-twice a week & $2(2.9 \%)$ & $2(2.9 \%)$ & $6(8.8 \%)$ & \\
\hline & 3 times/week or more & $2(2.9 \%)$ & $2(2.9 \%)$ & $4(5.9 \%)$ & \\
\hline \multirow[t]{4}{*}{ Feel very cold } & Never & $12(17.6 \%)$ & $4(5.9 \%)$ & $15(22.1 \%)$ & $0.504^{*}$ \\
\hline & Less than once a week & $1(1.5 \%)$ & $2(2.9 \%)$ & $2(2.9 \%)$ & \\
\hline & Once-twice a week & $3(4.4 \%)$ & $4(5.9 \%)$ & $7(10.3 \%)$ & \\
\hline & 3 times/week or more & $3(4.4 \%)$ & $5(7.4 \%)$ & $10(14.7 \%)$ & \\
\hline \multirow[t]{4}{*}{ To feel very hot } & Never & $11(16.2 \%)$ & $3(4.4 \%)$ & $15(22.1 \%)$ & $0.088^{*}$ \\
\hline & Less than once a week & $2(2.9 \%)$ & $5(7.4 \%)$ & $2(2.9 \%)$ & \\
\hline & Once-twice a week & $4(5.9 \%)$ & $3(4.4 \%)$ & $6(8.8 \%)$ & \\
\hline & 3 times/week or more & $2(2.9 \%)$ & $4(5.9 \%)$ & $11(16.2 \%)$ & \\
\hline \multirow[t]{4}{*}{ Have bad dreams or nightmares } & Never & $15(22.1 \%)$ & $7(10.3 \%)$ & $13(19.1 \%)$ & $0.051^{*}$ \\
\hline & Less than once a week & $1(1.5 \%)$ & $4(5.9 \%)$ & $4(5.9 \%)$ & \\
\hline & Once-twice a week & $2(2.9 \%)$ & $3(4.4 \%)$ & $7(10.3 \%)$ & \\
\hline & 3 times/week or more & $1(1.5 \%)$ & $1(1.5 \%)$ & $10(14.7 \%)$ & \\
\hline \multirow[t]{4}{*}{ To feel pain } & Never & $15(22.1 \%)$ & $8(11.8 \%)$ & $12(17.6 \%)$ & $0.007^{*}$ \\
\hline & Less than once a week & $0(0.0 \%)$ & $1(1.5 \%)$ & $2(2.9 \%)$ & \\
\hline & Once-twice a week & $4(5.9 \%)$ & $2(2.9 \%)$ & $6(8.8 \%)$ & \\
\hline & 3 times/week or more & $0(0.0 \%)$ & $4(5.9 \%)$ & $14(20 \%)$ & \\
\hline \multirow[t]{4}{*}{ Other reasons } & Never & $14(20.5 \%)$ & $9(13.2 \%)$ & $21(30.8 \%)$ & $0.668^{*}$ \\
\hline & Less than once a week & $1(1.5 \%)$ & $1(1.5 \%)$ & $0(0.0 \%)$ & \\
\hline & Once-twice a week & $2(2.9 \%)$ & $1(1.5 \%)$ & $5(7.4 \%)$ & \\
\hline & 3 times/week or more & $2(2.9 \%)$ & $4(5.9 \%)$ & $8(11.8 \%)$ & \\
\hline
\end{tabular}

Data expressed in absolute numbers (percentage). \# Fisher's Exact test; *Kruskal-Wallis test; $\mathrm{p}<0.05$ was considered a significant difference.

than 30 minutes to fall asleep and wake up in the middle of the night or too early, 19 (27.9\%) patients with both factors in the last month. In the nociceptive pain group, the factors that caused the most difficulty to fall asleep were wake up in the middle of the night or too early in the morning, $12(17.6 \%)$ patients; get up to go to the bathroom, $11(16.2 \%)$; and take more than 30 minutes to fall asleep, $6(8.8 \%)$ patients. All factors repeated three times or more per week. Feeling the pain and having bad dreams or nightmares were also preponderant factors, with a significant difference in the study among patients with neuropathic pain.

\section{DISCUSSION}

Some studies suggest that $90 \%$ of individuals with HIV have pain. Specifically, pain occurs for three main reasons: (1) HIV symptom; (2) another opportunistic disease or infection; (3) or adverse effect of the antiretroviral therapy (ART). The problem is even worse in cases of chronic pain associated with AIDS since there is a big negative interaction among the drugs used for analgesia and the antiretrovirals, making it difficult to treat the pain symptoms in these patients ${ }^{26}$. In addition, there is a higher incidence of adverse drug effects; greater under-treatment of pain in AIDS (85\%) than in cancer (49\%), and there is a worse scale of emotional well-being when compared with any chronic disease, regardless of the disease stage, except primary depression ${ }^{9,27}$.

According to the International Association for the Study of Pain (IASP), pain is "an unpleasant sensory and emotional experience associated with an existing or potential injury, or described in terms of such injury." When named as "chronic pain," it is characterized as continuous or recurrent pain, lasting at least for three months, often with uncertain etiology, and does not disappear with the use of conventional therapeutic procedures, becoming the cause of prolonged incapacity and disability ${ }^{28,29}$. This study confirms the data presented in the literature since almost $70 \%$ of the sample reported pain with chronicity. The interaction between antiretrovirals and 
drugs, such as cigarette and alcohol, is a risky behavior that can lead to toxicity and ineffective therapy; increased morbidity and mortality; increased exposure to high-risk sexual activity; acceleration of the disease progression; low adherence to ART; decline in $\mathrm{CD}^{+} \mathrm{T}$-cell lymphocytes and increase in viral load ${ }^{30}$. In this study, it was observed that $28.8 \%$ were smokers and $36.4 \%$ consumed alcohol, in these, neuropathic pain prevails.

Some studies have related the frequency of neuropathic pain with increased viral load and low CD4 levels, which did not present significance $(\mathrm{p}=0.138)$ in this sample. The use of the antiretroviral Efavirenz showed no significant association between the groups $(\mathrm{p}=0.409)$.

According to the data in table 2, there was no significant association between sociodemographic and clinical characteristics with the control and pain groups. A significant difference was observed between the gender ratio in the neuropathic pain group, women 32 and men 2, in comparison to the others, which is explained by the number of requests for care at the NGO where the study was performed.

Sleep is important to maintain the body homeostasis, and if it does not happen, the person will be subject to daytime sleepiness, fatigue, altered mood, and periods of disorientation. It may also reduce pain resistance because the fatigue of the sympathetic central nervous system is increased, which in turn causes an increase in the use of drugs to control pain, which contributes to sleep deprivation ${ }^{31}$. Therefore, sleep is a basic human need that deserves to receive all the attention and interventions from health professionals, especially the nurse ${ }^{32}$. According to Souza and Guimarães ${ }^{13}$, the human being needs to sleep, as he needs to breathe and feed. Sleeping is not a passive act, but rather a restful and active act, so its time should be respected and the less unregulated as possible ${ }^{33}$.

The number of sleeping hours varies among people according to gender, age, and biological constitution. Women sleep 40 to 50 minutes longer than men and have greater amount of deep sleep. In relation to age, sleep decreases during life. While a newborn sleeps up to 18 hours a day, a young person needs about seven to eight hours, and an old person may be satisfied with five hours. impaired sleep and inadequate wakefulness are invaluable sources of human suffering ${ }^{34}$.

The evidence indicates that deep sleep outweighs chronic painful processes so that patients with more hours of sleep probably experience the symptoms with less intensity. For Vasilceac ${ }^{35}$ a night's sleep of poor quality may increase pain sensitivity on the following day. This is evident in this sample because, on mean, the pain groups had fewer hours of sleep than the control group (no pain).

The response to pain is one of the behaviors that can be altered due to changes in the sleep pattern. Patients with chronic pain have sleep fragmentation, a condition that may increase pain. A study by Edwards et al. ${ }^{36}$ investigated the relationship between sleep duration and the presence of pain complaints in the population. They found that subjects who slept less than six hours or for nine hours or more reported pain more frequently on the following day, and those who slept for three hours or less had an $81 \%$ increase in pain frequency over the sleep period from 6 to 9 hours, and sleeping for more than 11 hours was associated with a $137 \%$ increase in pain frequency. Several authors stress the importance of a good night's sleep and its benefits. Moreover, there is an association between poor sleep and reduction in survival. Sleep disorders are typical signs of depression, as well as of pharmacological interactions, and it is necessary to investigate to solve this problem ${ }^{37}$.

Symptomatic or asymptomatic AIDS can lead to excessive daytime sleepiness (EDS) and insomnia. Studies with asymptomatic HIV patients have shown increased slow-wave sleep, especially during the second part of the night, as well as reduced sleep efficiency. As HIV progresses, sleep becomes more fragmented, with frequent arousal, the slow-wave sleep decreases and rhythmic REM/non-REM cycles are suppressed. Insomnia and fatigue are the most common complaints, but more than 100 other disorders have been identified. Among its main categories are the problems to keep a regular resting routine and unusual behaviors during sleep ${ }^{38}$.

According to Cruess et al., ${ }^{39}$ the presence of sleep disorders is of particular importance in HIV due to the already known adverse effects exerted by sleep deprivation on the immunity of healthy subjects and in HIV patients.

When comparing the overall score between the PSQI-BR components and the control, nociceptive and neuropathic pain groups, a significant association was found among patients with neuropathic pain who used sleeping pills $(\mathrm{p}<0.05)$. In this study, it was observed that more than $80 \%$ of the patients had poor sleep or sleep disorders. When compared to WHO data, ${ }^{17}$ that shows that $40 \%$ of the world population have difficulties in relation to the overall quality of sleep, the sample recorded the double of that loss of quality.

The Brazilian Society for the Study of Pain (SBED) $)^{40}$ describes that approximately $50 \%$ of patients with chronic pain report some sleep problems, such as difficulty in sleeping and awakening, closely associated with pain intensity. Many researchers and clinical practice professionals are becoming aware of the importance of the relationship between changes in time or quality of sleep and the presence of chronic pain. Although the mechanisms involved in this bidirectional relationship are still unclear, a good night's sleep can be an important tool to reduce pain complaints and improve patients' QoL ${ }^{40}$.

Studies related to sleep in patients with HIV/AIDS describe that these patients face a lot of stress during the course of the disease, including dependence, disability, fear of pain and painful death, which can lead to bad dreams and nightmares, such as presented in the sample. They also point out that pain, whether acute or chronic, associated with sleep disorders is an important public health problem, causing numerous damages, including human, occupational and labor injuries ${ }^{41}$.

It is known that pain interferes with sleep, but lack of sleep can increase the perception of pain ${ }^{42}$. Although there is a clear, strong relationship between pain and sleep, the reasons to explain it are unclear. The relationship between sleep and pain is bidirectional and more studies are still required. Also, both chronic pain and sleep disorders share a range of physical and 
mental health problems, such as obesity, type II diabetes, and depression. Having an interdisciplinary view is fundamental to understand the diagnosis better ${ }^{35}$. In 2017, SBED ${ }^{40}$ recommended that the teams who treat patients with these symptoms should be staffed by professionals from several areas.

Extended periods of rest deprivation may increase the risk of heart problems, as well as mental disorders or pain-related complaints ${ }^{43}$. The studies on the relationship between sleep and pain manifestations have intensified and confirmed their association. Individuals with chronic pain, for example, are also susceptible to severe sleep problems ${ }^{44}$. The circadian marker and the sleep homeostasis play central roles in the functions of daily life. Studies suggest that improved sleep enhances the immune function, both in cancer patients and in HIV-positive patients ${ }^{45}$.

Despite the benefits of antiretroviral therapy, AIDS has a physical, psychic and social impact. The nursing team seeks to improve its knowledge to provide individualized assistance in the different spaces where health care is provided. There is an increasing and continuous development towards comprehensive and personalized care, which allows nurses to plan their daily activities, enabling the development of nursing activity and valuing their knowledge $e^{46}$.

The nursing care directed to these patients should be performed with systematized actions in order to produce positive results in the care of these patients ${ }^{47}$. To obtain a satisfactory result with the treatment of pain, it is necessary to pay attention to the complaints related to sleep, characterizing and identifying these alterations to propose the required interventions to improve the QoL of these patients ${ }^{48}$.

\section{CONCLUSION}

There is a high prevalence of sleep disorders or poor sleep in HIV patients with neuropathic pain. There was also a higher number of patients with normal sleep efficiency in the neuropathic pain group, which may be related to the greater use of sleeping pills, practically the double of the other groups.

\section{REFERENCES}

1. Ministério da Saúde (BR), Secretária de Vigilância em Saúde, Programa Nacional de DST e AIDS. Protocolo Clínico e Diretrizes Terapêuticas para Manejo da Infecção pelo HIV em Adultos. Brasília, Ministério da Saúde.

2. Tortora GJ, Grabowski SR. Corpo humano: fundamentos de anatomia e fisiologia. $6^{a}$ ed. Porto Alegre: Artmed; 2006. 444-5p.

3. Brasil. UNAIDS, Estatísticas [Internet] 2016. [citado 2017 Abr 16]. Disponível em: http://unaids.org.br/estatisticas/.

4. Ministério da Saúde (BR), Departamento de DST, AIDS e Hepatites Virais. Dados Epidemiológicos de DST, HIV/AIDS. Boletim Epidemiológico HIV/AIDS. Brasília: Ministério da Saúde, 2016.

5. Marques MC. Saúde e poder: a emergência política da AIDS/HIV no Brasil. Hist Cienc Saúde. 2012;9(Suppl):41-65. Disponível em: http://dx.doi.org/10.1590/ S0104-59702002000400003.

6. Oliveira RM, da Silva LM. [Chronic pain related to AIDS: perspective of nurses and doctors]. Rev Bras Enferm. 2014;67(1) 54-61. Portuguese.

7. Kraychete DC, Sakata RK. Neuropatias periféricas dolorosas. Rev Bras Anestesiol. 2011;61(5): 649-58.

8. Baron R, Binder A, Wasner G. Neuropathic pain: diagnosis, pathophysiological mechanisms, and treatment. Lancet Neurol. 2010;9:807-19.

9. Teixeira MJ, Siqueira SRDT. Epidemiologia da dor, in: Alves Neto O, organizador. Dor: princípios e práticas. Porto Alegre: Artmed; 2009. 67-70p.
10. Kreling MC, da Cruz DA, Pimenta CA. Prevalence of chronic pain in adult workers] Rev Bras Enferm. 2006;59(4):509-13. Portuguese.

11. Júnior ED, Sousa MC. Epidemiology of chronic pain and neuropathic pain: developing a questionnaire for population-based surveys. 2003;60(8): [citado em $15 \mathrm{de} \mathrm{Abr}$ 2017]. Disponível em: http://www.saudeemmovimento.com.br/revista/artigos/rbm/ v60n8a3.pdf.

12. Larue F, Fontaine A, Colleau SM. Underestimation and undertreatment of pain in HIV disease: multicentre study. BMJ. 1997;314(7073):23-8.

13. Souza JC, Guimaraes LAM. Insônia e Qualidade de Vida. Campo Grande: UCDB; 1999.

14. Reite M, Ruddy J, Nagel K. Transtornos do Sono. 3a ed. Porto Alegre: Artmed; 2004. 444-5p.

15. Remiâo R. Sono - Aspectos Atuais. São Paulo: Atheneu; 1990.

16. Irwin M, Mascovich A, Gillin JC, Willoughby R, Pike J, Smith TL. Partial sleep deprivation reduces natural killer cell activity in humans. Psychosom Med. 1994;56(6):493-8.

17. World Health Organization (WHO/OMS). HIV/AIDS Program. Data and statistics. Global Epidemiology. [Internet] 2016. [citado em 28 de Jul 2017]: Disponível em: http://www.who.int/hiv/data/en/.

18. Cronfli RT. A importância do sono. Cérebro e Mente: Rev. Eletrônica de divulgação científica em Neurociência [Internet]. 2003. [citado em 15 de Abr 2017]. Disponível em: http://www.cerebromente.org.br/n16/opiniao/dormir-bem1.html.

19. Associação Brasileira do Sono (ABS). O sono normal e a privaçấo de sono. [Internet]. 2017. [citado em 28 de Abr 2017] Disponível em: http://www.absono.com.br/leigos/o-sono-normal-e-a-privacao-de-sono/.

20. Oliveira RM, Silva LM, Pereira ML, Gomes JM, Figueiredo SV, Almeida PC. Dor e analgesia em pacientes com síndrome da imunodeficiência adquirida. Rev Dor. 2012;13(4):332-7.

21. Muller MR, Guimaraes SS. Impacto dos transtornos do sono sobre o funcionamento diário e a qualidade de vida. Estud Psicol. 2007;24(4):519-28.

22. Santos EI, Gomes AM. Vulnerabilidade, empoderamento e conhecimento: memórias e representaçôes de enfermeiros acerca do cuidado. Acta Paul Enferm. 2013;26(5):492-8.

23. Bertolazi AN, Fagondes SC, Hoff LS, Dartora EG, Miozzo IC, de Barba ME, et al Validation of the Brazilian Portuguese version of the Pittsburgh Sleep Quality Index. Sleep Med. 2011;12(1):70-5.

24. Schestatsky P, Félix-Torres V, Chaves ML, Câmara-Ehlers B, Mucenic T, Caumo W, et al. Brazilian Portuguese validation of the Leeds Assessment of Neuropathic Symptoms and Signs for patients with chronic pain. Pain Med. 2011;12(10):1544-50.

25. Conselho Nacional de Saúde (CNS). Diretrizes e Normas Regulamentadoras de Pesquisas Envolvendo Seres Humanos. Resoluçāo 466/12. [Internet]. 2012. Disponível em: http://bvsms.saude.gov.br/bvs/saudelegis/cns/2013/res0466_12_12_2012.html

26. Ferreira LT, Ceolim MF. Sleep quality in HIV-positive outpatients. Rev Esc Enferm USP. 2012;46(4):892-9. Portuguese.

27. Silva JG, Morgan DA, Alchieri JC, Medeiros HF, Knackfuss MI. Nível de dor associado a variáveis sociodemográficas e clínicas em pessoas que vivem com o vírus da imunodeficiência humana e a síndrome da imunodeficiência adquirida. Rev Dor. 2017;18(1):51-8.

28. Merskey H, Bogduk N. Classification of chronic pain: descriptions of chronic pain syndromes and definitions of pain terms. $2^{\text {nd }}$ ed. IASP Press; 1994. [Internet]. 2017 [citado em 28 de Jul 2017] Disponível em: https://www.iasp-ain.org/PublicationsNews/Content.aspx?ItemNumber $=1673$.

29. Oliveira RM, da Silva LM, Pereira ML, Moura MA. [Pain management in patients with AIDS: analysis of the management structure of a reference hospital]. Rev Esc Enferm USP. 2013;47(2):456-63. Portuguese.

30. Santos VF, Galvão MT, Cunha GH, Lima IC, Gir E. Efeito do álcool em pessoas com HIV: tratamento e qualidade de vida. Acta Paul Enferm. 2017;30(1):94-100.

31. Smith MT, Haythornthwaite JA. How do sleep disturbance and chronic pain inter-relate? Insights from the longitudinal and cognitive-behavioral clinical trials literature. Sleep Med Rev 2004;8(2):119-32.

32. da Costa SV, Ceolim MF. [Factors that affect inpatients' quality of seep]. Rev Esc Enferm USP. 2013;47(1):46-52. Portuguese.

33. Togeiro SM, Smith AK. Métodos diagnósticos nos distúrbios do sono. Rev Bras Psiquiatr. 2005;27(1):8-15.

34. Reimấo RS. Estudo abrangente. $2^{a}$ ed. São Paulo: Atheneu; 1996.

35. Vasilceac FA. Estudos confirmam relaçáo entre dor crônica e falta de sono. [Internet]. 2017. [citado em 28 de Jul 2017] Disponível em: http://www.fai.ufscar.br/noticia/ estudos-confirmam-relacao-entre-dor-cronica-e-falta-de-sono.html.

36. Edwards RR, Almeida DM, Klick B, Haythornthwaite JA, Smith MT. Duration of sleep contributes to next-day pain report in the general population. Pain. 2008;137(1):202-7.

37. Silva JM, Costa AC, Machado WW, Xavier CL. Avaliação da qualidade de sono em idosos não institucionalizados. ConScientiae Saúde, 2012;11(1):29-36.

38. Norman SE, Chediak AD, Freeman C, Kiel M, Mendez A, Duncan R, et al. Sleep disturbances in men with asymptomatic human immunodeficiency (HIV) infection. Sleep. 1992;15(2):150-5.

39. Cruess DG, Antoni MH, Gonzalez J, Fletcher MA, Klimas N, Duran R, et al. Sleep disturbance mediates the association between psychological distress and immune status among HIV-positive men and women on combination antiretroviral therapy. J Psychosom Res. 2003;54(3):185-9.

40. Sociedade Brasileira para o Estudo da Dor (SBED). Dor e Sono. [Internet] 2017. [citado em 28 de Jul 2017]. Disponível em: www.sbed.org.br/materias.php?cd_secao=71. 
41. Galvão MT, Soares LL, Pedrosa SC, Fiuza ML, Lemos LA. Quality of life and adherence to antiretroviral medication in people with HIV. Acta Paul Enferm. 2015;28(1):48-53.

42. Redeker NS. Sleep in acute care settings: a integrative review. J Nurs Scholarsh. 2000;32(1):31-8

43. Coren S. Ladróes de sono: um alerta sobre o risco de contrariar nosso relógio biológico. Sấo Paulo: Cultura; 1996.

44. Instituto do Sono. Distúrbios do sono. [Internet] 2017. [citado em 28 de Abr 2017] Disponível em: http://www.sono.org.br/sono/disturbiosdosono.php.
45. Nokes KM, Kendrew M. Sleep quality in people with HIV disease. J Assoc Nurses AIDS Care. 1996;7(3):43-50.

46. Bergamasco EC, Cruz DA. Alteraçóes do sono: diagnósticos frequentes em pacientes internados. Rev. Gaúcha Enferm. 2006;27(3):356-63. Disponível em: http://seer. ufrgs.br/RevistaGauchadeEnfermagem/article/view/4624.

47. Horta, WA. Processo de enfermagem. Sáo Paulo: EPU;1979.

48. Nanda Internacional. Diagnósticos de enfermagem da NANDA: definiçốes e classificaçôes 2009-2011. Porto Alegre: Artmed; 2010. 